\title{
Clinical Outcome and Benefits with Bio Absorbable Coronary Stent
}

\author{
Sedigheh Asgary*1 and Anousheh Zargar Kharazi ${ }^{2}$ \\ ${ }^{1}$ Isfahan Cardiovascular Research Center, Isfahan University of Medical Sciences, Iran \\ ${ }^{2}$ Biomaterials Nanotechnology and Tissue Engineering Faculty, School of Advanced Medical Technology, Isfahan University of Medical Sciences ,Iran
}

Received: April 15, 2018; Published: April 24, 2018

*Corresponding author: Sedigheh Asgary, Isfahan Cardiovascular Research Center, Cardiovascular Research Institute, Isfahan University of Medical Sciences, Isfahan, Iran; Email: sedighehasgary@gmail.com

Abbreviations: BP: Bioabsorbable Polymer; BES: Biolimus-Eluting Stents; SES: Sirolimus-Eluting Stents; EES: Everolimus-Eluting; PES: Paclitaxel Eluting Stents; DES: Drug Eluting Stents; ZES: Zotarolimus-Eluting Endeavor

\section{Introduction}

Clinical trials including randomized clinical trial or nonrandomized (observational) can be categorized into comparative stent studies, either between
a) the two bioabsorbable stent generations; or
b) between bioabsorbable stent and other durable (or permanent, or biostable) stents; or

c) bioabsorbable stent assessment studies.

In most of studies the following bioabsorbable polymer-based drug eluting are used:
a) bioabsorbable polymer (BP)-based Biolimus-eluting stents (BP-BES);

b) bioabsorbable polymer-based Sirolimus-eluting stents (BP-SES);

c) bioabsorbable polymer Paclitaxel eluting stents (BP-PES);

d) Bioabsorbable polymer-based Everolimus-eluting (BPEES); and

e) bioabsorbable Rapamycin-eluting stents (BP-RES).

The comparator durable polymer drug eluting stents (DP-DES) are:

a) durable polymer Sirolimus eluting stents (DP-SES);

b) durable polymer Paclitaxel eluting stents (DP-PES);

c) durable polymer cobalt chromium Everolimus eluting stents (DP-CoCr-EES);

d) durable polymer platinum chromium Everolimus eluting stents (DP-PC-EES); e) durable polymer zotarolimus-eluting Endeavor(DPZES-E); and

f) Durable polymer Zotarolimus-eluting Resolute (DPZES-R). Some studies compared bioabsorbable DES with polymer free DES (PF-DES) [1]. The reported outcomes of the above mentioned clinical trials are major adverse cardiac events (MACE), which is a composite of adverse cardiac events including cardiac mortality, myocardial infarction (MI), and target lesion revascularization (TLR) and target vessel revascularization(TVR); all-cause-mortality; cardiac mortality; $\mathrm{MI}$; stent thrombosis (ST); late stent thrombosis(LST); TLR; and TVR.

\section{Non-Randomized (Observational)}

The three non-randomized clinical trials, which we described in this review, are:

i) Igaki;

ii) ABSORB;

iii) BIOSOLVE I.

which are summarized in Table 1. Igaki is the first fully biodegradable stent [Igaki-Tamai stent (Kyoto Medical Planning Co, Ltd, Kyoto, Japan)] implanted in human coronary arteries. Preliminary and 6-month results of Igaki stent suggested feasibility, safety and not stent thrombosis and no major cardiac event occurred within 30 days and no major cardiac event developed within 6 months. The 6-month follow-up of all patients showed acceptable restenosis and target lesion revascularization rate, and no deaths, myocardial infarctions or CABGs were recorded [2]. The Igaki-Tamai stent required 3 years to disappear from human coronary arteries. Clinical follow up rate was $100 \%$ at 4 years; $98 \%$ 
at 7 years and $96 \%$ at 10 years. Survival rates free of all-cause death, cardiac death and major adverse cardiac events (MACS) at 10 years were $87 \%, 98 \%$, and $50 \%$ respectively [3]. The cumulative rates Table 1: Non-Randomized (Observational) Clinical Trials on Bioabsorbable Coronary Stents. disappeared within 3 years.

of TLR were $16 \%$ at 1 year,18\% at 5 years and $28 \%$ at 10 years. Intravascular ultrasound data shows that the stent struts mostly

\begin{tabular}{|c|c|c|c|c|c|}
\hline $\begin{array}{c}\text { Clinical trial name/ } \\
\text { sample size }\end{array}$ & $\begin{array}{l}\text { intervention/ } \\
\text { comprator }\end{array}$ & Main outcome & $\begin{array}{l}\text { Study design/length } \\
\text { of study }\end{array}$ & & Ref. \\
\hline $\begin{array}{c}\text { Igaki } / \mathrm{N}=50 \\
10 \text { years }\end{array}$ & $\begin{array}{l}\text { IgaKI- Tamai stent } \\
\text { (made in kyoto } \\
\text { medical planning co, } \\
\text { Ltd, kyoto, Japan)It is } \\
\text { a coil stent made of } \\
\text { PLLA monofilamenta } \\
\text { and does not have any } \\
\text { drug elution }\end{array}$ & $\begin{array}{l}\text { all-cause death, cardiac } \\
\text { death and major } \\
\text { adverse cardiac events } \\
\text { (MACS);TLR,definite/ } \\
\text { probable scaffold } \\
\text { thrombosis }\end{array}$ & $\begin{array}{l}\text { observational } \\
\text { prospective cohort } \\
\text { study: single arm, } \\
\text { single center }\end{array}$ & $\begin{array}{l}\text { feasibility, safety and not } \\
\text { stent thrombosis and } \\
\text { no major cardiac event } \\
\text { occurred within } 30 \text { days } \\
\text { and no major cardiac } \\
\text { event developed within } 6 \\
\text { months.Acceptable MACS } \\
\text { and scaffold thrombosis } \\
\text { rates without stent recoil } \\
\text { and vessel remodeling } \\
\text { after } 10 \text { years suggested } \\
\text { long-term safety }\end{array}$ & $\begin{array}{l}\text { [Circulation_- } \\
\text { Igaki_2000] } \\
\text { [circulation_- } \\
\text { Igaki_2012] }\end{array}$ \\
\hline $\begin{array}{c}\text { BIOSOLVE I/ } \\
\mathrm{n}=46 \text { patients with } 47 \\
\text { lesions }\end{array}$ & $\begin{array}{l}\text { magnesium-based } \\
\text { paclitaxel-eluting } \\
\text { absorbable metal } \\
\text { scaffold }\end{array}$ & $\begin{array}{l}\text { Primary Outcome: Target } \\
\text { Lesion Failure [ Time } \\
\text { Frame: a composite of } \\
\text { cardiac death, target } \\
\text { vessel myocardial } \\
\text { infarction, and clinically } \\
\text { driven target lesion } \\
\text { revascularisation, at } 6 \text { and } \\
12 \text { months. Overall device } \\
\text { and procedural success } \\
\text { was } 100 \% \text {. target lesion } \\
\text { failureat } 6 \text { months and } 12 \\
\text { months were } 4 \% \text { and } 7 \% \\
\text { respectively with no safety } \\
\text { concern. }\end{array}$ & $\begin{array}{c}\text { prospective, } \\
\text { multicenter, Non- } \\
\text { Randomized Single } \\
\text { Group Assignment } \\
\text { Open Label/12 months }\end{array}$ & $\begin{array}{l}\text { feasibility, a good safety } \\
\text { profile, and promising } \\
\text { clinical and angiographic } \\
\text { performance results up } \\
\text { to } 12 \text { months }\end{array}$ & (BIOSOLVE-I) \\
\hline $\begin{array}{l}\text { ABSORB/cohort-A trial } \\
\text { enrolled } 30 \text { patients } \\
\text { /ABSORB cohort-B } \\
\text { enrolled } 101 \text { patients/ } \\
\text { 4 years }\end{array}$ & $\begin{array}{l}\text { BP-EES } \\
\text { poly-L-lactic acid } \\
\text { that provides the } \\
\text { support and a coating } \\
\text { of poly-D, L-lactic } \\
\text { acid that contain the } \\
\text { antiproliferative agent } \\
\text { everolimus }\end{array}$ & $\begin{array}{l}\text { cardiac death, myocardial } \\
\text { infarction, ischemia } \\
\text { driven target lesion } \\
\text { revascularization (TLR), } \\
\text { ischemia-driven major } \\
\text { advance cardiac event } \\
\text { (MACE) and stent } \\
\text { thrombosis }\end{array}$ & $\begin{array}{c}\text { Prospective } \\
\text { observational open- } \\
\text { label consists of } \\
\text { two different cohort } \\
\text { studies (cohort-A and } \\
\text { cohort-B) }\end{array}$ & $\begin{array}{c}\text { At four years } \\
\text { low ishamia-driven } \\
\text { MACE rate of } 3.4 \% \\
\text { without any late } \\
\text { complications such as } \\
\text { thrombosis and the } \\
\text { device was safe with } \\
\text { no cardiac deaths, no } \\
\text { ischemic-driven target } \\
\text { lesion revascularization } \\
\text { or scaffold patency and } \\
\text { target lesion restenosis }\end{array}$ & $\begin{array}{c}\text { [ABSORB_ } \\
\text { Lancet_2008]. }\end{array}$ \\
\hline
\end{tabular}

Due to the small number of patients, it is difficult to comment on events that have a low incidence, especially scaffold thrombosis. Late angiography and IVUS (intravascular ultrasound) were not dedicated by the protocol but was based on clinical indications. Therefore, angiography and IVUS follow-up studies were performed in a relatively small number of patients so there is the potential for bias. Acceptable MACS and scaffold thrombosis rates without stent recoil and vessel remodeling suggested a long-term ( $>10$ Years) safety of the Igaki-Tamai stent [3]. ABSORB cohort trial consists of two different cohort studies: i) cohort-A and ii) Cohort-B (B1, B2). The ABSORB cohort-A trial enrolled 30 patients with a single de novo native coronary artery lesion.

ABSORB cohort-B trial is the multi center, single-arm trial enrolled 101 patients with up to two de novo in a native coronary artery [ABSORB_Lancet_2008]. After two years, the stent was completely bio absorbed, vasomotion restored, and restenosis prevented with no compromise of luminal area, which means clinically safe, suggesting freedom from late thrombosis [4]. The fouryear clinical outcomes of the ABSORB cohort-A trial demonstrated a low ischaemia-driven MACE rate of $3.4 \%$ without any late complications such as thrombosis and the device was safe with no cardiac deaths, no ischemic-driven target lesion revascularization or any scaffold patency and target lesion restenosis [5,6]. Due to the small late recoil compared with conventional metallic platform stents, the following improvements were introduced to the secondgeneration bioabsorbable stent:

i) Enhancing mechanical strength;

ii) More durable support to the vessel wall; 
iii) Reducing maximum circular unsupported surface area; and

iv) Having a more uniform strut distribution and drug delivery.

The performance of this next- generation was subsequently investigated in the ABSORB Cohort B Trial, which was reported excellent clinical results up to 1-year follow-up [5,7]. There were no additional ID-MACE between six months and four years in the entire cohort; there was no instance of stent thrombosis according to either protocol or ARC definition [8,9]. Studying the clinical impact of acute scaffold disruption and late strut discontinuity of the second-generation revealed acute scaffold disruption was a rare phenomenon that has been associated with angina symptoms whereas late strut discontinuity was observed in approximately $40 \%$ of patients could be considered as an optical coherenc tomography finding of a normal bioresorption process without clinical implications [10].

BIOSOLVE-1 assessed the safety and performance of a new magnesium-based paclitaxel-eluting absorbable metal scaffold (DREAMS) in symptomatic patients with de-novo coronary lesions. Overall device and procedural success was $100 \%$.

Target lesion failure at 6 months and 12 months were 4\% and 7\%, respectively, with no safety concern. No cardiac death or scaffold thrombosis occurred [11].

\section{Randomized Clinical Trials}

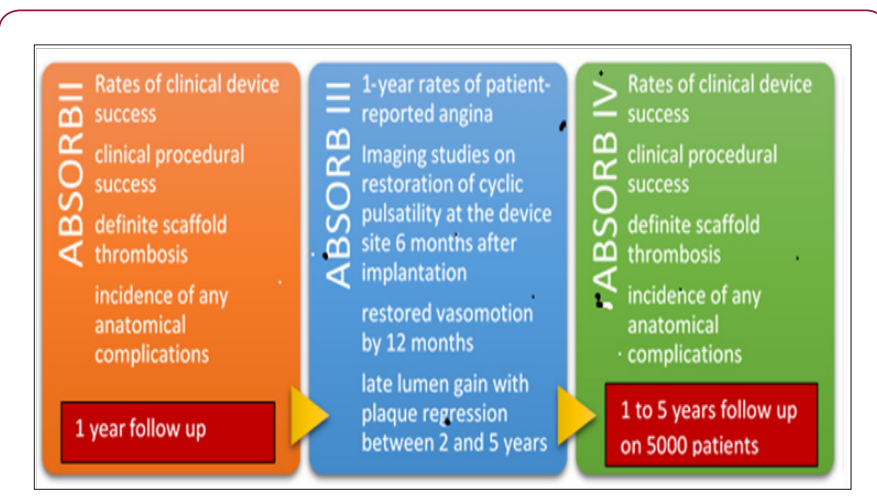

Figure 1: Clinical trial parameters for evaluate the safety and efficacy of the BP-EES Vs. metallic Everolimus-eluting stent XIENCE stent (CoCr-EES).

Figure 1. shows the Clinical trial parameters for evaluate the safety and efficacy of the BP-EES Vs. metallic Everolimus-eluting stent XIENCE stent (CoCr-EES) in ABSORB II, ABSORB III, ABSORB IV studies. ABSORB II study aiming to evaluate the safety and efficacy the BP-EES/metallic Everolimus-eluting stent XIENCE stent (CoCr-EES) [11]. Rates of clinical device success, clinical procedural success, definite scaffold thrombosis and the overall rate of definite or probable scaffold thrombosis and the incidence of any anatomical complications assessed by angiography were not significant between two treated groups. (ABSORB ii one year). In a post-hoc analysis, cumulative angina rates at 1 year were significantly lower in the bioresorbable scaffold group than in the metallic stent group. The BP-EES group also demonstrated less use of nitrates and less revascularization, which may have been driven by the reduction in angina [13] (Figure 1).

ABSORB III is much larger randomized trial compared with ABSORB II. As a result, the power of ABSORB III to detect differences in either efficacy or safety between the control metallic platform and BP-EES is going to be much greater [14]. The 1-year rates of patient-reported angina were also nearly identical with the two devices [15]. Imaging studies support the novel attributes of bioresorbable scaffolds with restoration of cyclic pulsatility at the device site 6 months after implantation, restored vasomotion by 12 months, and late lumen gain with plaque regression between 2 and 5 years, benefits that are not possible with permanent metallic stents [15-18]. However, if there are benefits from these attributes, they are likely to become evident only in the longer term. The ongoing ABSORB IV trial [ClinicalTrials.gov number, NCT02173379], which will enroll approximately 5000 patients, has a powered primary endpoint of improved rates of target-lesion failure at 1 to 5 years after implantation, an outcome that is designed to address this question. ABSORB IV is the continuation of ABSORB III and the data from ABSORB III and ABSORB IV will be pooled to support the ABSORB IV primary endpoint.

LEADER is a randomized Trial of Biolimus-eluting Stents with a Biodegradable Polymer versus Sirolimus-eluting Stents with a Durable Polymer [19]. (The safety benefit of the BP-BES compared with DP-SES was related to a significant reduction in very late ST ( $>1$ year) and associated composite clinical outcomes [20]. Biodegradable polymer BES maintained non-inferiority and improved long-term clinical outcomes compared to SES through 5 years $(\mathrm{P}=0.071)$ with $74 \%$ relative risk reduction in very late definite stent thrombosis. The benefit of biodegradable polymer BES emerged in the very late phase $[19,21]$. COSTAR II (Cobalt chromium Stent with Antiproliferative for Restenosis) trial is designed to compare BP-PES/DP-PES stent in single and multivessel percutaneous coronary intervention [22]. Paclitaxel elution from a stent coated with biostable polymer (TAXUS) reduces restenosis after PCI. The COSTAR DES is a novel stent with laser-cut reservoirs containing bioresorable polymer loaded to elute $10 \mathrm{~g}$ paclitaxel/30 days [23]. The COSTAR II study demonstrates that the COSTAR DES is no inferior in clinical and angiographic performance compared with the TAXUS DES. The relative benefit attributable to the TAXUS stent is predominantly due to lower rates of clinically driven TVR, with no differences observed in the incidences of death, MI, or stent thrombosis by the end of 9 months' follow-up [24].

NEVO RES-1 compared the NEVOTM sirolimus-eluting coronary stent system (NEVO SES) and the TAXUS LibertéTM paclitaxeleluting stent. Six-month angiographic results demonstrated the superiority of the NEVO SES over the TAXUS PES for the primary endpoint, in-stent late loss [nevores 6]. No stent thrombosis occurred in the NEVO SES group.No definite or probable stent thrombosis was recorded in the NEVO SES group at two years. Numerical differences favouring the NEVO SES that were observed at six months continued to increase over the 24 months of follow-up [25]. EVOLVE II (DP-PtCr-EES(PROMUS)/(SYNERGY) BP-PtCr-EES) 
supports the premise that the safety and efficacy of SYNERGY are at least comparable to the predicate PtCr durable polymer EES [26]. COMPARE II study is the first adequately powered trial to compare a biodegradable polymer-coated DES with Everolimus-eluting Xience as a gold standard, showed that a biodegradable polymer DES is at least as efficacious and safe as the Everolimus-eluting stent up to 12 months after implantation $[27,28]$.

Results of randomised trials and meta-analyses have shown that the second generation Eeverolimus-eluting stent significantly reduces the need for repeat revascularization and is also better at preventing stent thrombosis and myocardial infarction than are the early-generation sirolimus-eluting or paclitaxel-eluting stents.

Table 2: Randomized Clinical Trials on Bioabsorbtion Stents.
Therefore, the Everolimus-eluting Xience or Promus stents are the gold standard to which new stent designs should be compared [29]. SORT OUT V the effects of a biodegradable polymer biolimuseluting stent compared with a durable polymer-coated sirolimuseluting stent in 1229 patients (1532 lesions). The definite stent thrombosis at 12 months was significantly more in the biolimuseluting stent group than in the sirolimus-eluting stent group. At 1-year follow-up, the biodegradable polymer biolimus-eluting Nobori stent did not improve clinical results compared with a firstgeneration sirolimus-eluting stent. Long-term data and result are needed to make recommendations for the role of this biolimuseluting stent in routine clinical practice [30]. Table 2 presented summerized outcomes in randomized clinical trial (Table 2).

\begin{tabular}{|c|c|c|c|c|c|}
\hline $\begin{array}{c}\text { Clinical } \\
\text { Trial } \\
\text { Name/ } \\
\text { Sample Size }\end{array}$ & $\begin{array}{l}\text { Intervention/ } \\
\text { Comprator }\end{array}$ & Main Outcome & $\begin{array}{l}\text { Study Design/Length } \\
\text { of Study }\end{array}$ & & Ref. \\
\hline $\begin{array}{l}\text { ABSORB II } \\
\text { n=501 }(2: 1) \\
\text { ratio } / 3 \\
\text { years }\end{array}$ & $\begin{array}{l}\text { BP-EES/ } \\
\text { metallic } \\
\text { everolimus- } \\
\text { eluting stent } \\
\text { XIENCE stent } \\
\text { (CoCr-EES) }\end{array}$ & $\begin{array}{c}\text { Primary outcome } \\
\text { (vasomotion;minimum lumen diameter } \\
\text { at } 3 \text { years after nitrate admin-istration } \\
\text { minus minimum lumen diameter post } \\
\text { procedureafter nitrate administration; } \\
\text { Intravascular ultrasound secondary } \\
\text { endpoints; composite clinical secondary } \\
\text { endpoints;Scaff old or stent thrombosis } \\
\text { timing) }\end{array}$ & $\begin{array}{c}\text { randomized, active- } \\
\text { controlled, single- } \\
\text { blinded, multicenter (40 } \\
\text { center two-arm) }\end{array}$ & $\begin{array}{c}\text { At } 2 \text { years there were no } \\
\text { significant differences in the } \\
\text { clinical outcomes between the two } \\
\text { groups regarding PoCE (all death, } \\
\text { all MI and all revascularization) } \\
\text { and DoCE (cardiac death, TV-MI } \\
\text { and TLR) }\end{array}$ & \\
\hline $\begin{array}{l}\text { ABSORB III/ } \\
n=2008(2: 1 \\
\text { ratio) }\end{array}$ & $\begin{array}{l}\text { BP-EES / } \\
\text { everolimus- } \\
\text { eluting cobalt- } \\
\text { chromium } \\
\text { (Xience)CoCr- } \\
\text { EES; }\end{array}$ & $\begin{array}{l}\text { noninferiority (margin, } 4.5 \text { percentage } \\
\text { points for the risk difference) and } \\
\text { superiority, was target-lesion failure } \\
\text { (cardiac death, target-vessel myocardial } \\
\text { infarction, or ischemia-driven target- } \\
\text { lesion revascularization) at } 1 \text { year. }\end{array}$ & $\begin{array}{c}\text { multicenter, single- } \\
\text { blind, active-treatment, } \\
\text { controlled clinical trial/ } \\
5 \text { years }\end{array}$ & $\begin{array}{l}\text { target-lesion failure at } 1 \text { year } \\
\text { were } 1.7 \text { percentage points higher } \\
\text { in the Absorb group than in the } \\
\text { Xience group, a nonsignificant } \\
\text { difference that met the study } \\
\text { criteria for noninferiority } \\
\text { The 1-year rates of patient- } \\
\text { reported angina were also nearly } \\
\text { identical with the two devices. }\end{array}$ & $\begin{array}{c}\text { [ABSORB } \\
\text { III } \\
\text { DESIGN] }\end{array}$ \\
\hline $\begin{array}{c}\text { COMPARE } \\
\text { II } / \mathrm{n}=2707 / / \\
5 . \text { years }\end{array}$ & $\begin{array}{c}\text { BP-BES } \\
\text { (Nobori)/ } \\
\text { DP- Co Cr-EES } \\
\text { (Xience V) }\end{array}$ & $\begin{array}{l}\text { composite of safety (cardiac death and } \\
\text { non-fatal myocardial infarction) and } \\
\text { efficacy (clinically indicated target } \\
\text { vessel revascular- isation) at } 12 \text { months. } \\
\text { Secondary endpoints were a composite } \\
\text { of major adverse cardiac events (cardiac } \\
\text { death, non-fatal myocardial infarction, } \\
\text { and clinically driven target-lesion } \\
\text { revascularisation within a } 12 \text { month } \\
\text { follow- up) and a composite of cardiac } \\
\text { death, non-fatal myocardial infarction, } \\
\text { and target vessel revascularisation at } 3 \\
\text { and } 5 \text { years. }\end{array}$ & $\begin{array}{c}\text { open-label, prospective, } \\
\text { randomised, controlled, } \\
\text { non-inferiority trialat } 12 \\
\text { sites with no restrictions } \\
\text { on the number of lesions } \\
\text { or vessels to be treated, } \\
\text { the location of lesions, } \\
\text { or lesion length The only } \\
\text { inclusion criteriawere } \\
\text { age older than } 18 \text { years, } \\
\text { life expectancy of } 5 \text { years } \\
\text { or longer( }\end{array}$ & $\begin{array}{l}\text { Not any significant difference } \\
\text { fortheprimary composite } \\
\text { endpoint between stent types, } \\
\text { nor did the individual primary } \\
\text { endpoint components or the } \\
\text { stent thrombosis rates after } 12 \\
\text { months. BP-BES (Nobori) stent } \\
\text { are as safe and efficacious as the } \\
\text { current standard of a thin-strut } \\
\text { everolimus-eluting stent with a } \\
\text { durable biocompatible polymer. } \\
\text { DP- Co Cr-EES( Xience V) }\end{array}$ & \\
\hline $\begin{array}{l}\text { COMPARE } \\
\text { II } / \mathrm{n}=2707 / \\
(2 ; 1) / 5 \\
\text { years }\end{array}$ & $\begin{array}{c}\text { BP-BES } \\
\text { (Nobori)/ } \\
\text { DP-Co Cr- } \\
\text { EES(Xience V) }\end{array}$ & $\begin{array}{l}\text { composite of safety (cardiac death and } \\
\text { non-fatal myocardial infarction) and } \\
\text { efficacy (clinically indicated target } \\
\text { vessel revascular- isation) at } 12 \text { months. } \\
\text { Secondary endpoints were a composite } \\
\text { of major adverse cardiac events (cardiac } \\
\text { death, non-fatal myocardial infarction, } \\
\text { and clinically driven target-lesion } \\
\text { revascularisation within a } 12 \text { month } \\
\text { follow- up) and a composite of cardiac } \\
\text { death, non-fatal myocardial infarction, } \\
\text { and target vessel revascularisation at } 3 \\
\text { and } 5 \text { years. }\end{array}$ & $\begin{array}{l}\text { open-label, prospective, } \\
\text { randomised, controlled, } \\
\text { non-inferiority trial } \\
(02 ; 1) / 5 \text { years follow up }\end{array}$ & $\begin{array}{l}\text { Not any significant difference } \\
\text { for the primary composite } \\
\text { endpoint between stent types, } \\
\text { nor did the individual primary } \\
\text { endpoint components or the } \\
\text { stent thrombosis rates after } 12 \\
\text { months. BP-BES (Nobori) stent } \\
\text { are as safe and efficacious as } \\
\text { the current standard of a thin- } \\
\text { sturteverolimus-eluting stent with } \\
\text { a durable biocampatible polymer. } \\
\text { DP-Co Cr-EES (Xience V) }\end{array}$ & \\
\hline
\end{tabular}




\begin{tabular}{|c|c|c|c|c|c|}
\hline $\begin{array}{c}\text { (LEADERS) } \\
(\mathrm{N}=1,707) / \\
5 \text { years }\end{array}$ & BP-BES/DP-SES & $\begin{array}{l}\text { Assessed at } 5 \text { years) MACE } \\
\text { TLR, TVR;cardiac mortality, MI, and ST }\end{array}$ & $\begin{array}{l}\text { Multi-center (10 center), } \\
\text { assessor-blind, } \\
\text { noninferiority, "all- } \\
\text { comers"clinical trial }\end{array}$ & $\begin{array}{l}\text { After } 3 \text { year follow-up, there was } \\
\text { not any statistically significant } \\
\text { difference between BP-BES } \\
\text { and DP-SES in overall major } \\
\text { adverse cardiac events (MACE: a } \\
\text { composite of cardiac death, MI, } \\
\text { TVR), cardiac mortality, MI, TLR } \\
\text { and TVR, and ST. After5-year } \\
\text { follow-up, a statistically significant } \\
\text { reduction reported in very late } \\
\text { ST (> 1year) with BP-BES P = } \\
0.0034)]\end{array}$ & $\begin{array}{l}\text { [LEADER } \\
3 \text { year] } \\
\text { (LEADER } \\
5 \text { year) }\end{array}$ \\
\hline $\begin{array}{l}\text { (NEVORes- } \\
\text { Elution } \\
\text { IDuration: } 2 \\
\quad \text { years } \\
\text { months/394 }\end{array}$ & BP-SES/DP-PES & $\begin{array}{l}\text { Assessed at 6-month) } \\
\text { MACE; Death } \\
\text { MI; ST; TLR }\end{array}$ & $\begin{array}{c}\text { prospective } \\
\text { multicentrerandomised } \\
\text { study, (single de novo } \\
\text { lesions.) }\end{array}$ & $\begin{array}{l}\text { Proved the superiority of } \\
\text { NEVOSES over TAXUS Liberte PES } \\
\text { for the primary angiographic end } \\
\text { point of in-stent late loss }\end{array}$ & $\begin{array}{l}\text { [nevores } \\
2 \text { year] } \\
\text { [nevores } \\
6]\end{array}$ \\
\hline $\begin{array}{c}\text { COSTAR } \\
\text { II } \\
\text { Duration:9 } \\
\text { Month } \\
\mathrm{N}=1700 \\
\text { single- and } \\
\text { multivessel } \\
\text { (3:2 ratio) }\end{array}$ & BP-PES/DP-PES & $\begin{array}{l}\text { Assessed at } \\
\text { 8-month) } \\
\text { MACE; TVR }\end{array}$ & $\begin{array}{l}\text { prospective, multicenter, } \\
\text { noninferiority }(0 \\
\text { COSTAR versus } \\
\text { TAXUSstudy design }\end{array}$ & $\begin{array}{c}\text { CoStar DES is noninferior } \\
\text { in clinical and angiographic } \\
\text { performance compared with the } \\
\text { TAXUS DES }\end{array}$ & \\
\hline $\begin{array}{l}\text { EVOLVE II } \\
\text { n=1684 } \\
(1: 1)\end{array}$ & $\begin{array}{l}\text { platinum } \\
\text { chromium } \\
\text { (PtCr) metal } \\
\text { alloy stent } \\
\text { that elutes } \\
\text { everolimus } \\
\text { DP-PtCr- } \\
\text { EES(PROMUS)/ } \\
\text { (SYNERGY) } \\
\text { BP-PtCr-EES }\end{array}$ & $\begin{array}{l}\text { The primary end pointwas the rate of } \\
\text { 12-month target lesion failure (TLF); } \\
\text { Secondary clinical end points included } \\
\text { individual components of TLF, all-cause } \\
\text { death, and stent thrombosis }\end{array}$ & $\begin{array}{l}\text { prospective, multicenter } \\
(125 \text { clinical sites }) \\
\text { randomizedsingle- } \\
\text { blindnoninferiority trial }\end{array}$ & $\begin{array}{l}\text { supports the premise that the } \\
\text { safety and efficacy } \\
\text { of SYNERGY are at least } \\
\text { comparable to the predicate PtCr } \\
\text { durable polymer EES. }\end{array}$ & \\
\hline $\begin{array}{l}\text { SORT OUT V } \\
/ \mathrm{n}=2468\end{array}$ & $\begin{array}{l}\text { BP-BES } \\
\text { (nobori)/DP- } \\
\text { SES (Cypher } \\
\text { Select Plus) }\end{array}$ & $\begin{array}{l}\text { the primary endpoint-a } \\
\text { composite of safety (cardiac death, } \\
\text { myocardial infarction, } \\
\text { defi nite stent thrombosis) and effi } \\
\text { cacy (target vessel } \\
\text { revascularisation) }\end{array}$ & & $\begin{array}{l}\text { At 1-year follow-up, the } \\
\text { biodegradable polymer biolimus- } \\
\text { eluting Nobori stent did not } \\
\text { improve clinical results compared } \\
\text { with a first-generation sirolimus- } \\
\text { eluting stent. }\end{array}$ & \\
\hline
\end{tabular}

\section{Discussion}

In the LEADERS (Limus Eluted from A Durable versus ERodable Stent coating) trial, a biolimus-eluting bioabsorbable polylactic-acid polymer-coated stent was compared with a firstgeneration sirolimus-eluting stent with a durable vinyl-acrylate copolymer showed non-inferiority between both stent types at 9 months and 12 months, ( LEADERS) but after 4 years follow-up the definite very late ( $>1$ year) stent thrombosis rate and the number of patients reaching the primary endpoint (composite of cardiac death, myocardial infarction, and clinically indicated target vessel revascularization) were significantly lower with the biolimuseluting stent than with the sirolimus-eluting stent [21]. This finding is particularly relevant because definite late stent thrombosis is associated with serious events such as myocardial infarction and mortality. Longer-term follow-up of the COMPARE II trial will show whether the beneficial effect of the biodegradable polymer biolimus-eluting stent on late stent thrombosis also applies when compared with newer-generation DES. A comprehensive network meta-analysis compared major differences in safety and efficacy of BP-BES with BMS and durable polymer eluting stents including DPPES, DP-SES, DP-EES (DP-CoCr-EES, DP-PtCr-EES) and DP-ZES (DPPC-ZES, DP-Re- ZES) [31].

In this large-scale network meta-analysis, BP-BES were associated with superior clinical outcomes compared with BMS and first-generation DES and similar rates of cardiac death/MI, MI, and TVR compared with second-generation DP-DES but higher rates of definite ST than CoCr-EES(31).Risk for definite ST with BP-BES compared with CoCr-EES was apparent both in the early period (before 30 days) and the late period (between 30 days and 1 year) but conversely, a nonsignificant trend was present for a 
reduced rate of very late ST (beyond 1 year) with BP-BES compared with CoCr-EES. These data demonstrate that use of BP might not be associated with the lowest risk of ST, especially within the first year after stent implantation. Polymers requiring active bio resorption have historically been associated with greater rates of inflammation than DP. Moreover, although polylactic acid (the BP used in the Biomatrix and Nobori stents [Terumo Corporation] in the present report) induces relatively low levels of inflammation, other BP might theoretically be more inert and/or completely resorb faster (e.g., in 3 months compared with 6 to 9 months in the current BP-BES), permitting the late benefits of BP-DES to emerge at an earlier time period.

Therefore, any potential advantages of BP-based DES over biocompatible DP-based stents might not emerge until the late follow-up period after biodegradation of the polymer and largescale studies will be required to determine whether the potential late benefits of a BP can more than offset the early benefits of a thromboresistant DP. SES and PES were associated with the highest rates of ST beyond 1 year, significantly higher than with BMS, BPBES, CoCr-EES, and PC-ZES. Thus, some of the late benefit seen in randomized trials of BP-BES compared with first-generation DES such as LEADERS, NEVORes-Elution and COSTAR might relate more to the poor safety profile of the comparator stent rather than to specific benefits of the BP itself. The best-in-class secondgeneration DES to determine meaningful differences is CoCr-EES then the result of COMPARE II AND ABSORB III and ABSORB IV will be conclusive.

In the metaanalysis (from 126 randomized trials Twenty-eight trials randomized patients to a biodegradable polymer drug eluting stent, and the rest used durable polymer drug eluting stents) reported a statistically significant decrease in stent thrombosis (ST) events in BP-BES compared with DP-SES and statistically significant less MI, TVR and ST events were reported in BP- BES compared with DP-PES. It was also observed that BP-BES had statistically significant lower TVR compared with DP-ZES-E: The results of this study, showed that biodegradable polymer drug eluting stents are superior to first generation durable polymer drug eluting stents but are not superior to newer generation durable polymer drug eluting stents for either efficacy or safety outcomes. Newer generation durable polymer stents (cobalt chromium everolimus eluting stents, platinum chromium everolimus eluting stents, and zotarolimus eluting stent-Resolute) were the most effective stents in having the lowest rate of repeat revascularization, no increase in Table 3: Clinical Outcomes With Bioabsorbable Polymer/Durable Polymer-Based Drug-Eluting and Metal Stents From MetaAnalysis.

\begin{tabular}{|l|r|}
\hline Considered stents & Reasults \\
\hline & $\begin{array}{r}\text { Ref. } \\
\text { superior clinical outcomes of BP-BES compared with BMS and first- } \\
\text { generation DES. } \\
\text { similar rates of cardiac death/MI, MI, and TVR in BP-BES } \\
\text { compared with second-generation DP-BES } \\
\text {-higher rates of definite ST ofBP-DES than CoCr-EES }\end{array}$ \\
\hline
\end{tabular}

very late stent thrombosis, and a significant decrease in the risk of myocardial infarction. But one of the most important point is that the following time is mean of 2.3 (range $0.5-5$ ) years, that means the result is not conclusive [32].

A meta-analysis of 5834 patients revealed not any significant differences in terms of overall mortality, MI, late ST, and TLR between bioabsorbable DES including BP-BES or BP-SES, and durable DES including DP-PES, DP-SES, DP- ZES [33]. In a metaanalysis comprising data for 3738 patients in six trials (ABSORB China, ABSORB Japan, EVERBIO II, TROFi II) randomized to receive either an everolimus-eluting bioresorbable vascular scaffold $(n=2337)$ or an everolimus-eluting metallic stent $(n=1401)$ and median follow-up 12 months (IQR 9-12) are analyzed. Metallic stent was either a cobalt-chromium stent (Xience V, Xience Prime, or Xience Expedition, Abbott Vascular, Santa Clara, CA, USA; n=1321) or a platinum-chromium stent (Promus Element, Boston Scientific, Natick, MA, USA; $n=80$ ) [34]. Findings showed that bioresorbable vascular scaffolds had a similar risk of repeat revascularization as metallic stents, a higher risk of stent (scaffold) thrombosis at 1 year of follow-up, and an inferior mid-term angiographic performance. The primary benefit of biodegradable versus metallic stents is expected to emerge several years after percutaneous coronary interventions, when the elution of anti-restenotic drug is completed and the bioresorbable scaffold is dissolved.

At least similar efficacy and safety versus the existing best-inclass drug-eluting stent at 12 months is important. The rate and the timing of definite or probable stent thrombosis in patients who received a bioresorbable vascular scaffold was consistent with that reported in other studies, with most events occurring within 30 days [34]. Studies with extended follow-up in a larger number of patients are needed to fully assess the expected longterm advantages of everolimus-eluting bioresorbable vascular scaffolds. A summary of meta-analysis results on Bioabsorbable Polymer/Durable Polymer-Based Drug-Eluting and Metal Stents are presented in (Table 3). Randomized clinical trials (SPIRIT and COMPARE) and meta-analyses have revealed that the second generation everolimus-eluting stent significantly reduces the need for repeat revascularization and better prevent stent thrombosis and myocardial infarction than are the early-generation sirolimuseluting or paclitaxel-eluting stents $(35,36)$. Therefore, the Everolimus-eluting Xience or Promus stents are the gold standard to which new stent designs should be compared [29]. (Table 3) 


\begin{tabular}{|c|c|c|}
\hline & $\begin{array}{c}\text { decrease in stent thrombosis (ST) events in BP-BES compared with } \\
\text { DP-SESand statistically significant less MI, TVR and ST events were } \\
\text { reported in BP- BES compared with DP-PES. It was also observed that } \\
\text { BP- BES had statistically significant lower TVR compared with DP- } \\
\text { ZES-E: }\end{array}$ & Bangalore \\
\hline $\begin{array}{c}\text { BP-BES/ Newer generation } \\
\text { durable polymer stents (cobalt } \\
\text { chromium everolimus eluting } \\
\text { stents, platinum chromium } \\
\text { everolimus eluting stents, and } \\
\text { zotarolimus eluting stent- } \\
\text { Resolute) }\end{array}$ & $\begin{array}{c}\text { Newer generation durable polymer stents were the most effective } \\
\text { stents in having the lowest rate of repeat revascularization, no increase } \\
\text { in very late stent thrombosis, and a significant decrease in the risk of } \\
\text { myocardial infarction. }\end{array}$ & Bangalore \\
\hline $\begin{array}{c}\text { bioabsorbable DES (BP-BES or } \\
\text { BP-SES)/durable DES (DP-PES, } \\
\text { DP-SES, DP- ZES) }\end{array}$ & $\begin{array}{c}\text { not any significant differences in terms of overall mortality, MI, late ST, } \\
\text { and TLR }\end{array}$ & \\
\hline
\end{tabular}

A pooled analysis from three large-scale multicenter randomized clinical trials (ISAR-TEST 3, ISAR-TEST 4, and LEADERS) included 4062 patients of which 2358 patients had been randomly assigned to treatment with biodegradable polymer DES (1501 patients with sirolimus- eluting and 857 patients with Biolimus-eluting stents) and 1704 patients to treatment with durable polymer SES assessed clinical outcomes for 4 years follow-up. The efficacy endpoint was target lesion revascularization and the safety endpoint was definite stent thrombosis. The risk of target lesion revascularization and the risk of definite stent thrombosis were significantly lower among patients treated with biodegradable polymer DES vs. durable polymer SES. In landmark analysis between 1 and 4 years, the incidence of myocardial infarction was significantly lower for patients treated with biodegradable polymer DES vs. durable polymer. Importantly, this difference was not apparent when the trials included in this study were analyzed separately. The result showed improved safety and efficacy of Biodegradable polymer DES compared with durable polymer SES during long-term followup to 4 years $[37,38]$.

Although the one of the limitation of this pooled analysis is that only sirolimus - eluting durable polymer were included in this study and the result cannot be extended to other available stents and may be overestimated.

A pooled analysis of three RCTs (ISAR-TEST 3, ISAR-TEST 4, and LEADERS) comparing BP-DES (BP-BES and BP-SES), with DP-SES reported, BP- DES was associated with a statistically significant lower rate of MI and ST compared with DP-DES. However, no difference between BP-DES and DP-DES was indicated in other clinical outcomes such as all-cause mortality, cardiac mortality, cardiac mortality/ML and TLR up to 4 years follow- up [38]. The comparative effectiveness of BP-DES with DP-DES in patients with coronary artery disease who have undergone PCI is inconsistent and inconclusive, depending on the types of stents and the eluting drugs. Better designed RCTs and cost-effectiveness analysis in Canadian settings are needed to determine whether BP-DES could replace DP-DES in the treatment of patients with CAD requiring PCI. No studies were identified evaluating the cost-effectiveness of bioabsorbable polymer DES compared with durable polymer or polymer free DES for adult's CAD. No guidelines regarding the use of bioabsorbable stents for adults with CAD were found.

\section{Conclusion}

Clinical outcome and benefits of bioabsorbable and durable stent was considered by non-randomized and randomized clinical trial. large-scale network meta-analysis showed that there are not any significant differences in terms of overall mortality, MI, late ST, and TLR between Bioabsorbable DES including BP-BES or BP-SES, and durable DES including DP-PES, DP-SES, DP- ZE and bioresorbable vascular scaffolds had a similar risk of repeat revascularization as metallic stent. However, the risk of target lesion revascularization and the risk of definite stent thrombosis were significantly lower among patients treated with biodegradable polymer DES vs. durable polymer SES. Also, lower rate of MI and ST was observed in patient with BP-BES compared those with DP-DES. Studies with extended follow-up in a larger number of patients are needed to fully assess the expected long-term advantages of everolimuseluting bioresorbable vascular scaffolds.

\section{References}

1. Dehghani P (2017) Bioresorbable Polymers and Stent Devices. Current Treatment Options in Cardiovascular Medicine 19(2): 12.

2. Tamai H, Igaki K, Kyo E, Kosuga K, Kawashima A, et al. (2000) Initial and 6-month results of biodegradable poly-l-lactic acid coronary stents in humans. Circulation 102(4): 399-404.

3. Nishio S, Kosuga K, Igaki K, Okada M, Kyo E, et al. (2012) Long-term (>10 Years) clinical outcomes of first-in-human biodegradable poly-l-lactic acid coronary stents: Igaki-Tamai stents. Circulation 125(19): 23432352.

4. Serruys PW, Ormiston JA, Onuma Y, Regar E, Gonzalo N, et al. (2009) A bioabsorbable everolimus-eluting coronary stent system (ABSORB): 2 -year outcomes and results from multiple imaging methods. Lancet 373(9667): 897-910.

5. Dudek D, Onuma Y, Ormiston JA, Thuesen L, Miquel Hebert K, et al. (2012) Four-year clinical follow-up of the ABSORB everolimus-eluting bioresorbable vascular scaffold in patients with de novo coronary artery disease: The ABSORB trial. EuroIntervention 7(9): 1060-1061.

6. Gonzalo N, Macaya C (2012) Absorbable stent: Focus on clinical applications and benefits. Vascular Health and Risk Management 8: 125132.

7. windecker S (2013) The Absorb Cohort B Trial: Insights from Longitudinal Imaging Follow-Up From Six Months To Three Years. J Am Coll Cardiol 61(10): E1643-1645.

8. Cutlip DE, Windecker S, Mehran R, Boam A, Cohen DJ, Van Es GA, et al. (2007) Clinical end points in coronary stent trials: A case for standardized definitions. Circulation 115(17): 2344-2251. 
9. Serruys PW, Onuma Y, Ormiston JA, De Bruyne B, Regar E, Dudek D, et al. (2010) Evaluation of the second generation of a bioresorbable everolimus drug-eluting vascular scaffold for treatment of de novo coronary artery stenosis: Six-month clinical and imaging outcomes. Circulation 122(22): 2301-2312.

10. Onuma Y, Serruys PW, Muramatsu T, Nakatani S, Van Geuns RJ, et al. (2014) Incidence and imaging outcomes of acute scaffold disruption and late structural discontinuity after implantation of the absorb everolimus-eluting fully bioresorbable vascular scaffold: Optical coherence tomography assessment in the ABSORB cohort B Trial (. JACC Cardiovasc Interv 7(12): 1400-1111.

11. Haude M, Erbel R, Erne P, Verheye S, Degen H, et al. (2016) Safety and performance of the DRug-Eluting Absorbable Metal Scaffold (DREAMS) in patients with de novo coronary lesions: 3-year results of the prospective, multicentre, firstin-man BIOSOLVE-I trial. EuroIntervention 12(2): e160-166

12. Diletti R, Serruys PW, Farooq V, Sudhir K, Dorange C, et al. (2012) ABSORB II randomized controlled trial: A clinical evaluation to compare the safety, efficacy, and performance of the Absorb everolimus-eluting bioresorbable vascular scaffold system against the XIENCE everolimuseluting coronary stent system in the treatm. Am Heart J 164(5): 654-663.

13. Serruys PW, Chevalier B, Dudek D, Cequier A, Carrié D, et al. (2015) A bioresorbable everolimus-eluting scaffold versus a metallic everolimuseluting stent for ischaemic heart disease caused by de-novo native coronary artery lesions (ABSORB II): An interim 1-year analysis of clinical and procedural secondary outcomes from. Lancet 385(9962): 43-54.

14. Kereiakes DJ, Ellis SG, Popma JJ, Fitzgerald PJ, Samady H, et al. (2015) Evaluation of a fully bioresorbable vascular scaffold in patients with coronary artery disease: design of and rationale for the ABSORB III randomized trial. Am Heart J 170(4): 641-651.

15. Ellis SG, Kereiakes DJ, Metzger DC, Caputo RP, Rizik DG, et al. (2015) Everolimus-Eluting Bioresorbable Scaffolds for Coronary Artery Disease. N Engl J Med 373(20): 1905-1915.

16. Serruys PW, Onuma Y, Garcia Garcia HM, Muramatsu T, Van Geuns RJ, et al. (2014) Dynamics of vessel wall changes following the implantation of the Absorb everolimus-eluting bioresorbable vascular scaffold: A multiimaging modality study at 6,12, 24 and 36 months. EuroIntervention 9(11): 1271-84.

17. Santoro G, Meucci F, Stolcova M, Rezzaghi M, Mori F, et al. (2016) Percutaneous left atrial appendage occlusion in patients with nonvalvular atrial fibrillation: Implantation and up to four years follow-up of the AMPLATZER Cardiac Plug. EuroIntervention 11(10): 1188-1194.

18. Ormiston JA, Serruys PW, Onuma Y, Van Geuns RJ, De Bruyne B, et al. (2012) First serial assessment at 6 months and 2 years of the second generation of ABSORB everolimus-eluting bioresorbable vascular scaffold a multi-imaging modality study. Circ Cardiovasc Interv 5(5): 620-632.

19. Wykrzykowska J, Serruys P, Buszman P, Linke A, Ischinger T, et al. (2011) The three-year follow-up of the randomised "all-comers" trial of a biodegradable polymer biolimus-eluting stent versus permanent polymer sirolimus-eluting stent (LEADERS). EuroIntervention J Eur Collab with Work Gr Interv Cardiol Eur Soc Cardiol 7(7): 789-795.

20. Serruys PW, Farooq V, Kalesan B, de Vries T, Buszman P, et al. (2013) Improved safety and reduction in stent thrombosis associated with biodegradable polymer-based biolimus-eluting stents versus durable polymer-based sirolimus-eluting stents in patients with coronary artery disease: final 5-year report of the LEADERS (Limus. JACC Cardiovasc Interv 6(8): 777-789.

21. Stefanini GG, Kalesan B, Serruys PW, Heg D, Buszman P, et al. (2011) Long-term clinical outcomes of biodegradable polymer biolimus-eluting stents versus durable polymer sirolimus-eluting stents in patients with coronary artery disease (LEADERS): 4-year follow-up of a randomised non-inferiority trial. Lancet 378(9807): 1940-1948.

22. Wang TY, Hasselblad V, Peterson JL, Wijns W, Parhizgar A, et al. (2007) The Cobalt Chromium STent with Antiproliferative for Restenosis II (COSTAR II) Trial study design: Advancing the active-control evaluation of second-generation drug-eluting stents. Am Heart J 153(5): 743-748.

23. Harrington J, Vaughan R, Jow K, Pippey W, Chen YM (2017) Laser system and processing conditions for manufacturing bioabsorbable stents. Google Patents.

24. Krucoff MW, Kereiakes DJ, Petersen JL, Mehran R, Hasselblad V, et al. (2008) A novel bioresorbable polymer paclitaxel-eluting stent for the treatment of single and multivessel coronary disease: primary results of the COSTAR (Cobalt Chromium Stent With Antiproliferative for Restenosis) II study. J Am Coll Cardiol 51(16): 1543-1552.

25. Abizaid A, Ormiston JA, Fajadet J, Mauri L, Schofer J, et al. (2013) Two-year follow-up of the NEVO ResElution-I(NEVO RES-I) trial: A randomised, multicentre comparison of the NEVO sirolimus-eluting coronary stent with the TAXUS Liberté paclitaxel-eluting stent in de novo native coronary artery lesions. EuroIntervention 9(6): 721-729.

26. Kereiakes DJ, Meredith IT, Windecker S, Lee Jobe R, Mehta SR, et al. (2015) Efficacy and safety of a novel bioabsorbable polymer-coated, everolimus-eluting coronary stent: the EVOLVE II Randomized Trial. Circ Cardiovasc Interv 8(4): e002372.

27. Smits PC, Hofma S, Togni M, Vázquez N, Valdés M, et al. (2013) Abluminal biodegradable polymer biolimus-eluting stent versus durable polymer everolimus-eluting stent (COMPARE II): A randomised, controlled, noninferiority trial. Lancet 381(9867): 651-660.

28. Smits PC, Kedhi E, Royaards KJ, Joesoef KS, Wassing J, et al. (2011) 2 -year follow-up of a randomized controlled trial of everolimus- and paclitaxel-eluting stents for coronary revascularization in daily practice: COMPARE (Comparison of the everolimus eluting XIENCE-V stent with the paclitaxel eluting TAXUS LIBERT stent in. J Am Coll Cardiol 58(1): 11-18.

29. Ormiston JA, Webster MWI (2012) Stent thrombosis: Has the firestorm been extinguished? The Lancet 379(9824): 1368-1369.

30. Christiansen EH, Jensen LO, Thayssen P, Tilsted HH, Krusell LR, et al. (2013) Biolimus-eluting biodegradable polymer-coated stent versus durable polymer-coated sirolimus-eluting stent in unselected patients receiving percutaneous coronary intervention (SORT OUT V): A randomised non-inferiority trial. Lancet 381(9867): 661-669.

31. Palmerini T, Biondi Zoccai G, Della Riva D, Mariani A, Sabaté M, et al. (2014) Clinical outcomes with bioabsorbable polymer- Versus durable polymer-based drug-eluting and bare-metal stents: Evidence from a comprehensive network meta-analysis. J Am Coll Cardiol 63(4): 299307.

32. Bangalore S, Toklu B, Amoroso N, Fusaro M, Kumar S, et al. (2013) Bare metal stents, durable polymer drug eluting stents, and biodegradable polymer drug eluting stents for coronary artery disease: mixed treatment comparison meta-analysis. BMJ 347: f6625-f6625.

33. Lupi A, Rognoni A, Secco GG, Lazzero M, Nardi F, et al. (2014) Biodegradable versus durable polymer drug eluting stents in coronary artery disease: Insights from a meta-analysis of 5834 patients. Eur J Prev Cardiol 21(4): 411-424.

34. Cassese S, Byrne RA, Ndrepepa G, Kufner S, Wiebe J, et al. (2016) Everolimus-eluting bioresorbable vascular scaffolds versus everolimuseluting metallic stents: A meta-analysis of randomised controlled trials. Lancet 387(10018): 537-544.

35. Palmerini T, Biondi Zoccai G, Riva D Della, Stettler C, Sangiorgi D, et al. (2012) Stent thrombosis with drug-eluting and bare-metal stents: Evidence from a comprehensive network meta-analysis. Lancet 379(9824): 1393-1402. 
36. Stone GW, Rizvi A, Sudhir K, Newman W, Applegate RJ, et al. (2011) Randomized comparison of everolimus- and paclitaxel-eluting stents: 2-year follow-up from the SPIRIT (clinical evaluation of the XIENCE v everolimus eluting coronary stent system) IV trial. J Am Coll Cardiol 58(1): $19-25$

37. De Winter RJ, Katagiri Y, Asano T, Milewski KP, Lurz P, et al. (2017) A sirolimus-eluting bioabsorbable polymer-coated stent (MiStent) versus an everolimus-eluting durable polymer stent (Xience) after percutaneous coronary intervention (DESSOLVE III): a randomised, single-blind, multicentre, non-inferiority, phase 3 trial. Lancet 391(10119): 431-440.

38. Stefanini GG, Byrne RA, Serruys PW, De Waha A, Meier B, et al. (2012) Biodegradable polymer drug-eluting stents reduce the risk of stent thrombosis at 4 years in patients undergoing percutaneous coronary intervention: a pooled analysis of individual patient data from the ISARTEST 3, ISAR-TEST 4, and LEADERS randomized tria. Eur Heart J 33(10): 1214-1222.

\section{(c) (i) \\ This work is licensed under Creative Commons Attribution 4.0 License}

Submission Link: https://biomedres.us/submit-manuscript.php

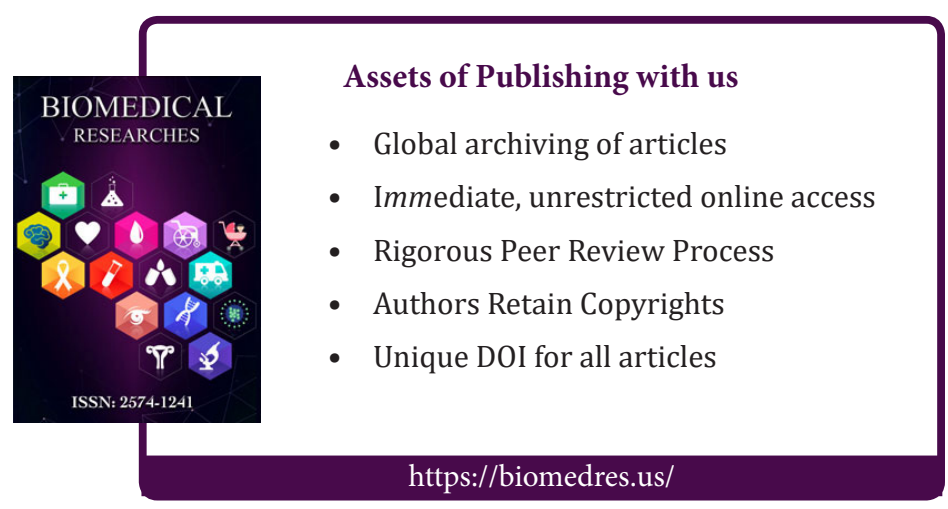

